\title{
A CASE OF AGGRESSIVE ANGIOMYXOMA PRESENTING AS A HUGE VULVAL GROWTH
}

Purvita Dam¹, Suhrita De(Roy)2, Indranil Banerjee³, Partha Sarathi Chakravorty ${ }^{4}$.

1. Associate professor, Department of Gynaecology \& Obstetrics, North Bengal Medical College

2. Assistant professor, Department of Gynaecology \& Obstetrics, Medical College Kolkata.

3. RMO Cum Clinical Tutor, Department of Gynaecology \& Obstetrics, Malda Medical College.

4. Professor \& H.O.D, Department of Gynaecology \& Obstetrics, Malda Medical College.

\section{CORRESPONDING AUTHOR:}

Purvita Dam,

26 sarat chatterjee road,

Kolkata-700089

E-mail: purvita_mdgo@yahoo.com

INTRODUCTION: Aggressive Angiomyxoma is a rare tumor of mesenchymal origin initially described in 1983 by Steeper and Rosai and fewer than 150 cases have been reported in World literature since then. ${ }^{1}$ The reported age at presentation is 6-77 years, with the peak incidence occurring during the reproductive years. The female to male ratio is 6:1. ${ }^{2}$ Aggressive Angiomyxoma chiefly involves the deep soft tissues of the vulvovaginal region, perineum and pelvis. It is a slow growing tumor, but problematic due to frequent local recurrences, incidence in patient with narrow surgical margins is not higher than the one in patients with wide surgical margins. ${ }^{2}$ The typical characteristics include slow growth, gelatinous appearance and locally infiltrative, but nonmetastasizing in nature without evidence of nuclear atypia or mitosis.

CASE REPORT: $35 \mathrm{yr}$ old Mrs A.P., P2 +0 presented with huge irregular swelling arising from the vulva, growing for the last six months with sudden increase in size in the past one month. On examination the patient had this swelling mainly arising from the right labia, measuring approximately $30 \times 20 \mathrm{cms}$ and another smaller one arising from the other labia too.

The growth was multicentric in origin with smaller elements arising from perineum and perianal areas too. Apart from generalized discoid lupus erythematous like lesions on the skin for which she received dapsone, no other significant medical or surgical history was present. Routine investigations were within normal limits. She was seronegative for HIV and syphilis. Wedge biopsy from the mass revealed cutaneous candidiasis for which she was put on weekly fluconazole. After one month of therapy the angry looking mass gradually turned to one with a much regular contour, but size remained unaltered. Keeping a provisional diagnosis of vulval elephantiasis in mind, we went for wide excision of the mass with atleast $1 \mathrm{~cm}$ tumor free margin on all sides and sites on $8^{\text {th }}$ September 2010.

The mass weighed around $3 \mathrm{~kg}$. Post-operative period was uneventful. Surprisingly the report revealed aggressive angiomyxoma of vulva. Judging its notorious nature of recurrence the patient has since been regularly followed up every month and has had a speedy recovery 
DISCUSSION: The pathogenesis is unclear, but recently a translocation at chromosome 12 with a consequent aberrant expression of the high-mobility group protein isoform I-C (HMGIC) protein involved in DNA transcription was demonstrated. ${ }^{3}$

As in our case, mostly it presents as a slow-growing vulvar mass. It is soft and easily compressible. It has no capsule, can invade the paravaginal and pararectal spaces displacing the pelvic organs, and may extend retroperitoneally. Considering the hugeness of our case, rarely seen in world reports the common differential diagnosis kept in mind included vulval filarial elephantiasis or elephantiasis nostras, following tubercular lymphatic obstruction. Microscopically, there was loosely textured myxoid stroma with small clusters of mesenchymal, stellate cells, and spindle-shaped cells. Neoplastic cells are considered to be derived from the stromal cells, which express fibroblastic or myofibroblastic features. Prominent vascular pattern were present in which the dilated vessels of varying sizes are distributed haphazardly in a myxoid background

Fingerlike projections are seen at the periphery and into the surrounding tissue. Immunohistochemistry was positive for desmin, vimentin, and smooth muscle actin. ${ }^{4}$

Wide surgical excision is the traditional treatment of choice. Where fertility is to be preserved or surgery is likely to be extensive and mutilating, incomplete resection is acceptable as local recurrences can be treated with further resection. ${ }^{5}$ Recurrence is frequent in about $30 \%$ to $40 \%$, and may occur from months to several years after excision deeming longterm follow-up necessary. 6 This woman has been advised regular checkups, with a plan for repeat excision or treatment with GnRH agonists in case of recurrence.

The case is reported because of the unique presentation as after several browsing we did not come across such big angiomyxoma confusing the initial provisional diagnosis

(Fig 1) The huge vulval growth arising from both labia majora

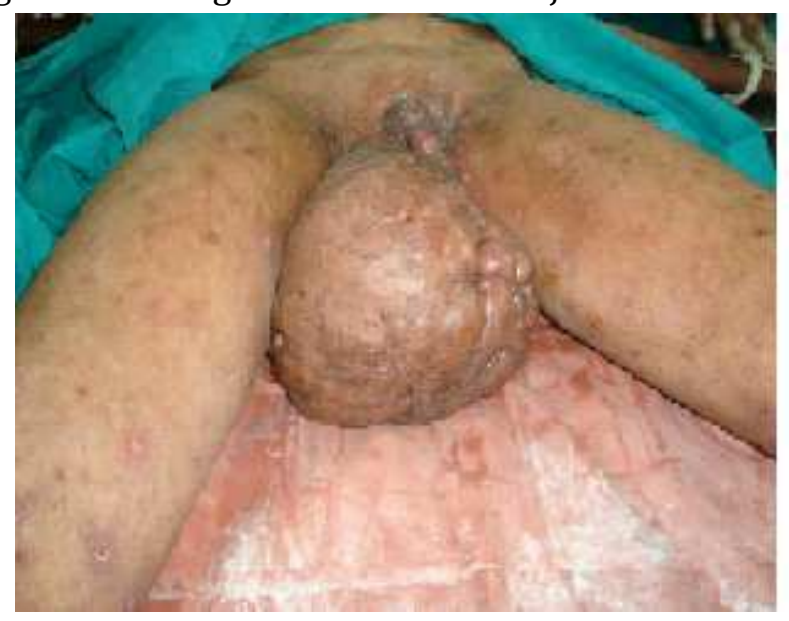




\section{CASE REPORT}

(Fig 2) Just prior to excision

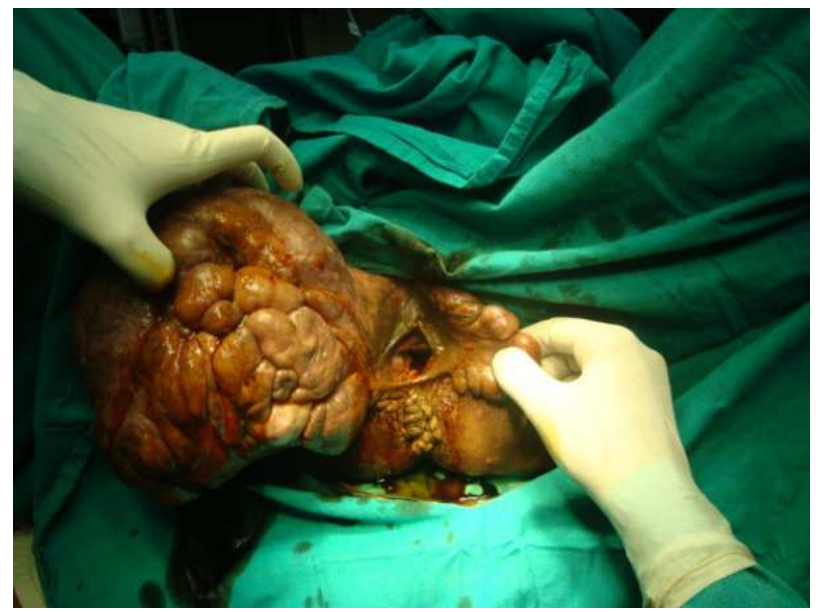

Fig 3- Per-operative

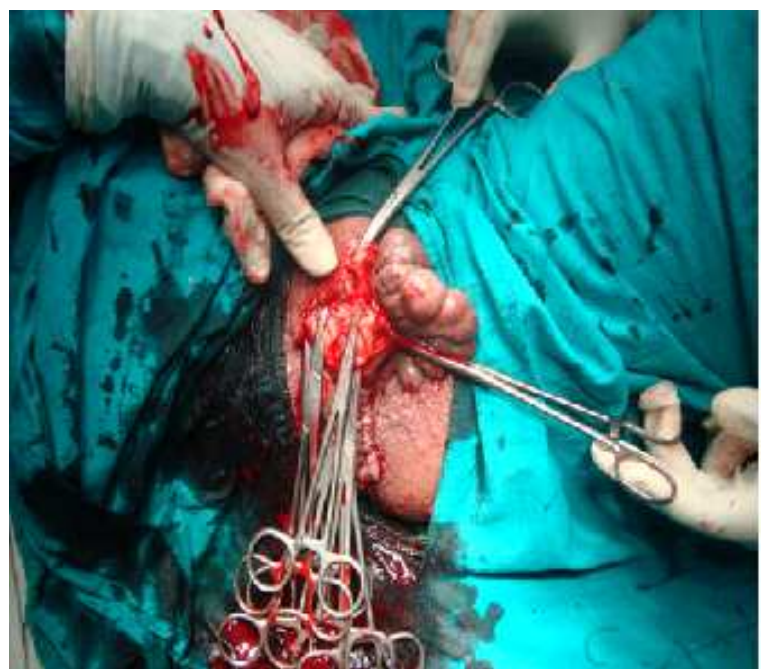

Fig 4- The mass from right labia majora

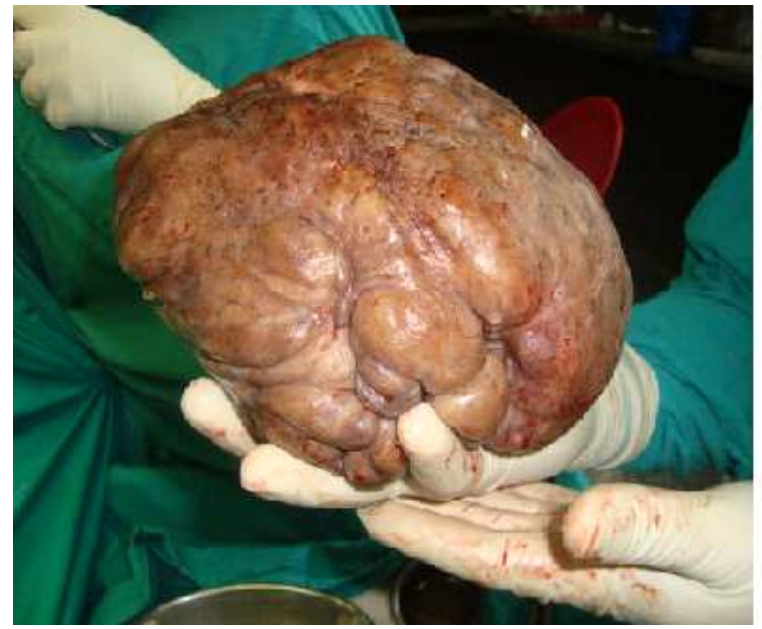




\section{CASE REPORT}

(Fig 5) (Low power field) The arrows showing angiogenic (square) and myxomatous (rectangle) components.

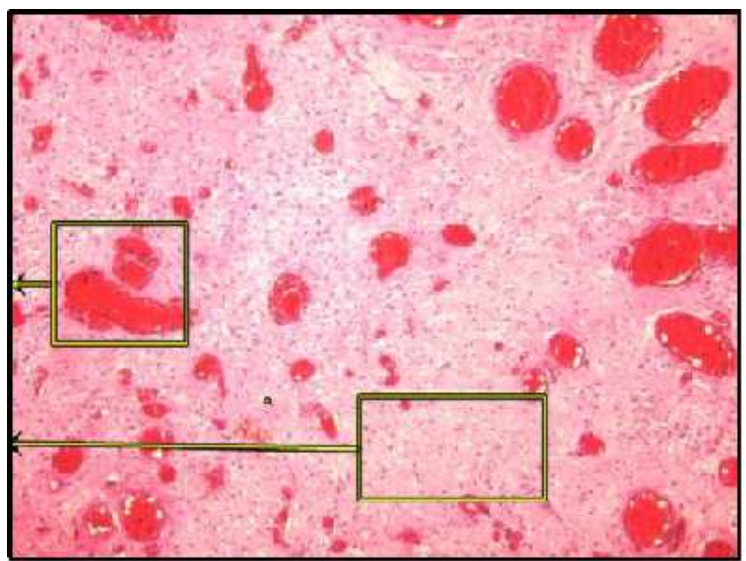

(Fig 6) (High power field) The arrows showing angiogenic (square) and myxomatous (rectangular) components.

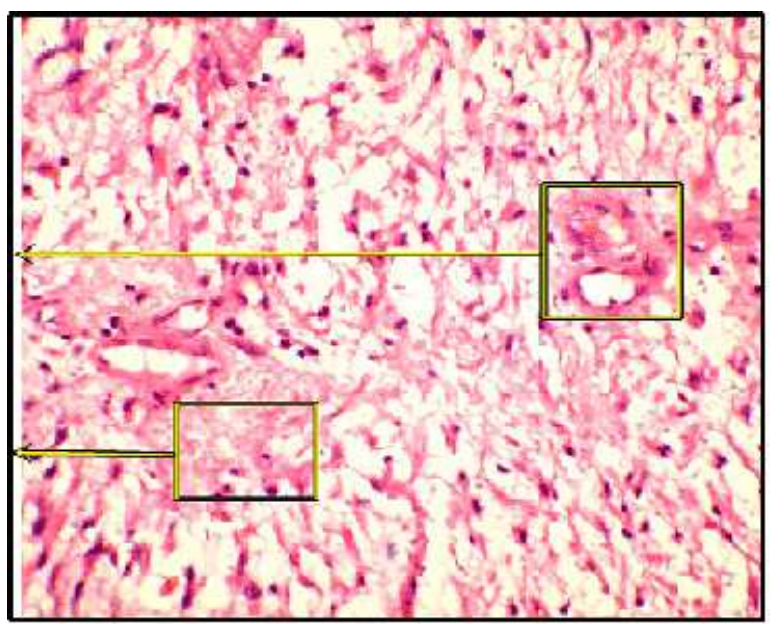

Fig 7- When she came for follow-up

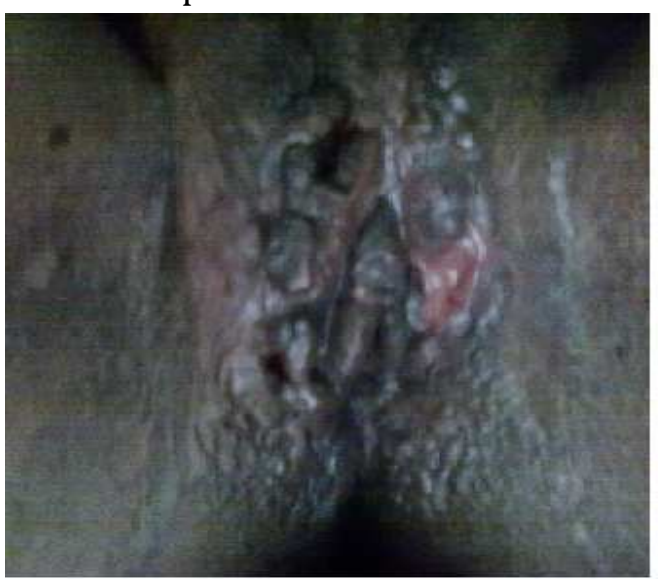




\section{CASE REPORT}

\section{REFERENCES-}

1) Steeper TA, Rosai J. Aggressive angiomyxoma of the female pelvis and perineum. Report of nine cases a distinctive type of gynecologic soft-tissue neoplasm. Am J Surg Pathol. 1983; 7:463-475.

2) Han-Geurts IJ, van Geel AN, van Doorn L, den Bakker M, Eggermont AM, Verhoef C. Aggressive angiomyxoma: multimodality treatments can avoid mutilating surgery. Eur J Surg Oncol. 2006; 32:1217-1221.

3) Magtibay PM, Salmon Z, Keeney GL, Podratz KC. Aggressive angiomyxoma of the female pelvis and perineum: a case series. Int J Gynecol Cancer. 2006; 16:396-401.

4) Mc Cluggage WG, Patterson A, Maxwell P. Aggressive angiomyxoma of pelvic parts exhibits estrogen and progesterone receptor positivity. J Clin Pathol. 2000; 53:603-605.

5) Chan YM, Hon E, Ngai SW, Ng TY, Wong LC, Chan IM. Aggressive angiomyxoma in females: is radical resection the only option? Acta Obstet Gynecol Scand. 2000; 79:216-220.

6) Behranwala KA, Thomas JM. Aggressive angiomyxoma: a distinct clinical entity. Eur J Surg Oncol. 2003;29:559-563 